\title{
Effects of different returning method combined with decomposer on decomposition of organic components of straw and soil fertility
}

\section{Xiao Wang}

Shenyang Agricultural University

\section{Xuexin Wang}

Shenyang Agricultural University

\section{Peng Geng}

Shenyang Agricultural University

\section{Qian Yang}

Shenyang Agricultural University

\section{Kun Chen}

Shenyang Agricultural University

Ning Liu

Shenyang Agricultural University

\section{Yueling Fan}

Chinese Academy of Sciences

Xiumei Zhan ( $\nabla$ xiumeizhan@163.com )

Shenyang Agricultural University

\section{Xiaori Han}

Shenyang Agricultural University

\section{Research Article}

Keywords: straw decomposition, soil fertility, plant science

Posted Date: April 8th, 2021

DOl: https://doi.org/10.21203/rs.3.rs-389287/v1

License: (c) (i) This work is licensed under a Creative Commons Attribution 4.0 International License. Read Full License

Version of Record: A version of this preprint was published at Scientific Reports on July 29th, 2021. See the published version at https://doi.org/10.1038/s41598-021-95015-5. 



\title{
Effects of different returning method combined with decomposer on decomposition of organic components of straw and soil fertility
}

\author{
Xiao Wang ${ }^{1}$, Xuexin Wang ${ }^{1}$, Peng Geng ${ }^{1}$, Qian Yang ${ }^{1}$, Kun Chen ${ }^{1}$, Ning Liu ${ }^{1}$, Yueling \\ Fan $^{2}$, Xiumei Zhan ${ }^{1 *}$, Xiaori Han ${ }^{1 *}$ \\ ${ }^{1}$ College of Land and Environment, Shenyang Agricultural University, Shenyang 110866, China \\ ${ }^{2}$ Institute of Applied Ecology, Chinese Academy of Sciences, Shenyang 110016, China \\ *Corresponding: Xiumei Zhan, xiumeizhan@163.com; Xiaori Han, hanxiaori@163.com
}

\section{ABSTRACT}

In view of the problems of low straw decomposition rates and reduced soil fertility in southern Liaoning, China. Using nylon mesh bags method, the decomposition rules of cellulose, hemicellulose and lignin in straw and straws and the dynamic changes of soil organic carbon (SOC), soil microbial biomass carbon (MBC) and soil dissolved organic carbon (DOC) contents were analyzed after 15, 35, 55, 75, 95, 145 and 365 days of returning. At 365 days after return to the field, rotating tillage + straw decomposing agent(refer to decomposer)(RT+S) was the most favorable for straw decomposition and its components, straw decomposition proportion reached $73.25 \%$, and the decomposition proportion of lignin, cellulose and hemicellulose were the highest, being $35.49 \%, 84.23 \%$ and $85.50 \%$, respectively. DOC content in $\mathrm{RT}+\mathrm{S}$ treatment was higher than in other treatments at each stage, SOC content reached $18.02 \mathrm{~g}^{\cdot} \mathrm{kg}^{-1}$ at $145 \mathrm{~d}$, which was higher than other treatments. The improvement effect of deep turning + deep rotary tillage + straw decomposing agent $(P T+S)$ treatment on microbial biomass carbon (MBC) was the best, followed by $R T+S$ treatment. Our results suggest that the straw and its organic components decomposition proportion could be increased by adding straw decomposing agent, the straw decomposition proportion and the SOC content of various forms were significantly increased with the $\mathrm{RT}+\mathrm{S}$ treatment.

\section{Introduction}

The total amount of straw in China is large, and the annual output has exceeded 900 million tons ${ }^{1}$. With inappropriate disposal of agricultural waste presenting a major threat to the environment ${ }^{2}$. Crop straw burning has numerous detrimental effects on soil and air quality ${ }^{3}$. Straw is an important biomass resource and should be used rationally. Returning straw to the field is important for soil fertilization ${ }^{4}$, as it not only improves soil structure, but also soil organic carbon storage ${ }^{5,6}$. It is well known that straw incorporation is beneficial to the concentration and storage of $\mathrm{SOC}^{7}$, while nutrient availability in the soil, conversely, influences the straw decomposition rate $^{8}$. Tillage methods, air temperature, and precipitation affect soil temperature, moisture, porosity and microbial activity ${ }^{9-11}$, and these affect crop straw soil decomposition and nutrient changes, and ultimately, soil fertility ${ }^{12}$. Soil temperature and moisture especially, have been identified as key environmental factors regulating soil organic matter and straw decomposition ${ }^{13-16}$. Returning straw to the field under different tillage methods leads to different soil layer ranges, and environmental temperature and straw moisture status, which affects straw decomposition processes and forms of soil organic carbon ${ }^{17}$. Presently, there are two main ways of returning straw to the field: mulching and burying. No-tillage mulching has the least soil disturbance, and increasing crop residue could reduce soil erosion ${ }^{18-20}$. However, straw decomposition rate when placed on the soil surface is lower than when buried in the soil ${ }^{21,22}$. Under the condition of straw burying, the decomposition process is different due to different straw depth ${ }^{23}$. Studies have shown that, in no tillage straw returning treatment, straw was exposed to the air, lack of full contact with soil and water, low microbial activity and low 
decomposition intensity of straw. Rotary tillage straw returning treatment, straw and soil fully mixed, soil ventilation and water permeability is good, $0-20 \mathrm{~cm}$ temperature is higher than no tillage mulch, which is conducive to soil microbial decomposition of straw, thus promoting the decomposition of straw ${ }^{24}$.

To promote straw decay and ensure normal production of the next crop, a straw decomposing agent is sometimes applied. A straw decomposition agent is a type of microbial agent composed of a variety of microbial communities, which can accelerate degradation through the catabolism of fungi, bacteria and actinomycetes to decompose cellulose hemicellulose and lignin into small molecular organic compounds and minerals ${ }^{25}$. The agent can prevent or reduce the adverse effect of excessive straw retention on crop growth, thus stabilizing and increasing soil nutrient content and significantly increasing straw decomposition rate ${ }^{26}$.

Presently, there are many reports on the effects of tillage methods on straw decomposition and soil fertility indexes, but few on decomposition characteristics of straw organic components and the dynamic changes of different forms of soil organic carbon under different straw return methods combined with a decomposing agent. Therefore, we studied: (1) influences of return methods and decomposition agent on decomposition characteristics of straw and its components and the dynamic changes of soil organic carbon content, and (2) regulation of straw decomposition rules, to provide a reference for the rational utilization of local straw.

\section{Materials and methods}

Site Description. The experimental was conducted in Gengzhuang Town, Haicheng $\left(40^{\circ} 48^{\prime} \mathrm{N}, 122^{\circ}\right.$ $37^{\prime}$ E), Liaoning Province from 2019 to 2020. This area is belonged to the conti-nental monsoon climate zone of warm temperate zone, the annual average tempera-ture is above $10{ }^{\circ} \mathrm{C}$, the annual accumulated temperature is $3000-3100{ }^{\circ} \mathrm{C}$, the frost-free period is about 170 days, and the annual rainfall is $600-800$ $\mathrm{mm}$. The soil type is brown soil. Before the experiment, the concentration of soil organic matter, total nitrogen, available nitrogen, available phosphorus, available potassium, and soil bulk density in $0-20 \mathrm{~cm}$ surface layer were $12.01 \mathrm{~g} \cdot \mathrm{kg}^{-1}, 0.89 \mathrm{~g} \cdot \mathrm{kg}^{-1}, 129.6 \mathrm{mg} \cdot \mathrm{kg}^{-1}, 25.96 \mathrm{mg} \cdot \mathrm{kg}^{-1}, 117.94 \mathrm{mg} \cdot \mathrm{kg}^{-1}$, and 1.53 $\mathrm{g} \cdot \mathrm{cm}^{-3}$, respectively. The components and nutrient contents of corn straw were shown in Table 1, The average temperature and precipita-tion from May 2019 to May 2020 are shown in Figure 1.

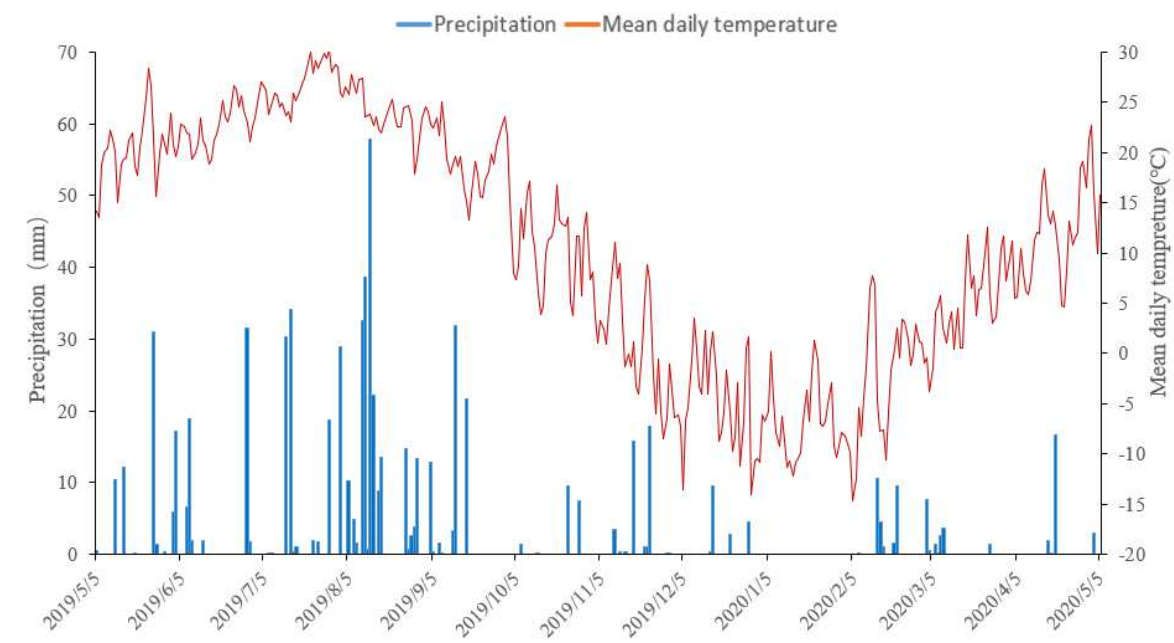

Figure 1. Daily precipitation and mean air temperature during the straw decomposition period from May 2019 to May 2020.

Table 1. Initial component content of corn straw.

\begin{tabular}{ccccccc}
\hline Cellulose \% & Hemicellulose \% & Lignin \% & $\mathrm{C} \%$ & $\mathrm{~N} \%$ & $\mathrm{P} \%$ & $\mathrm{~K} \%$ \\
\hline 32.14 & 34.37 & 10.25 & 36.90 & 0.92 & 0.22 & 0.86 \\
\hline
\end{tabular}


Experimental design and management. We adopted a split plot design, with the main plot as the cultivation method, and with three cultivation options: no-tillage, deep turning + deep rotary tillage and rotary tillage. Then, when adding straw as a decomposing agent, two methods were used: adding straw decomposing agent and not adding it. Our experimental approach included six treatments: No-tillage mulching and straw return to the field + straw decomposing agent; no-tillage mulching and straw return to the field + no straw decomposing agent; rotating tillage and straw return to the field + straw decomposing agent; rotating tillage and straw return to the field + no straw decomposing agent; deep turning + deep rotary tillage and straw return to the field + straw decomposing agent; and deep turning + deep rotary tillage and straw return to the field + no straw decomposing agent. Each treatment was replicated 3 times, located in random blocks, with a total plot area of $68.4 \mathrm{~m}^{2}$. At the same time as the previous year's corn harvest, straw was returned to the field, crushed to about $10 \mathrm{~cm}$ long, spread evenly on the ground. No-tillage mulching and straw return to the field is the direct no-tillage maize sowing operation in spring; in deep turning + deep rotary tillage treatment, deep turning is used to loosen the soil to a depth of $35 \mathrm{~cm}$, and then the straw is mixed into the soil through deep rotary tillage (a depth of 30 $\mathrm{cm}$ ); and rotating tillage involves mixing straw into the soil with a rotary tiller to a depth of $20 \mathrm{~cm}$ and then raking it flat.

Using the nylon net bag method (mesh bags were $5 \mathrm{~cm} \times 6 \mathrm{~cm}$, small; $15 \mathrm{~cm} \times 20 \mathrm{~cm}$, medium; and large, $25 \mathrm{~cm} \times 35 \mathrm{~cm}$; each size with an aperture of $100 \mathrm{mesh}$ ), we simulated three return modes. Soil added to the net bags was taken from the top 0-20 cm prior to sowing in 2019, in the corresponding plots of each treatment. Corn stalks were added at a ratio of 5:4 per stem and leaf (dry weight of stem and leaf of corn stalks in mature stage), and crushed to $2 \mathrm{~cm}$ long. In no-tillage treatment, $10 \mathrm{~g}$ straw was added to the medium mesh bag, in the rotary tillage and deep turning + deep rotary tillage treatment, $10 \mathrm{~g}$ straw was evenly divided into five parts and put into five small net bags, then the five small net bags were evenly mixed into the soil of the outer large net bag and sealed, and the compactness between the inner net bag and the soil in the outer net bag was adjusted.

Net bag layout was determined according to different treatment tillage patterns, and bags were placed in the field on seeding day in 2019. Deep turning + deep rotary tillage was achieved by ploughing furrows $30 \mathrm{~cm}$ long, $15 \mathrm{~cm}$ wide, and $35 \mathrm{~cm}$ deep between corn rows in corresponding plots, large net bags were buried vertically in the furrows, filled with soil and compacted, so that return depth and straw distribution were basically the same as deep turning + deep rotary tillage in the field. Rotating tillage was achieved by ploughing furrows $30 \mathrm{~cm}$ long, $15 \mathrm{~cm}$ wide, and $20 \mathrm{~cm}$ deep between corn rows in the corresponding treatment plot, the packed net bags were tilted in the furrows, filled with soil and moderately compacted, the top end of the net bags was level with the ground surface, which is basically consistent with the return depth of rotary tillage and straw distribution in actual field production. No-tillage mulching treatments involved laying the net bags containing straw on the ground and covering the four corners with soil to prevent the net bag from being blown away by the wind. The decomposing agent addition treatments involved evenly spraying c. $6.5 \mathrm{ml}$ straw decomposing agent on the straw surface before bagging.

In all treatments we applied the same amount of $\mathrm{N}, \mathrm{P}$ and $\mathrm{K}\left(\mathrm{N} 240 \mathrm{~kg} \cdot \mathrm{hm}^{-2}, \mathrm{P}_{2} \mathrm{O}_{5} 74 \mathrm{~kg} \cdot \mathrm{hm}^{-2}\right.$ and $\mathrm{K}_{2} \mathrm{O}$ $89 \mathrm{~kg} \cdot \mathrm{hm}^{-2}$ ). The nitrogen fertilizer was urea, the phosphate fertilizer superphosphate, and the potassium fertilizer, potassium chloride. The brand of straw decomposition agent is Gainby and the model number is d-68 (created by NORDOX company and produced by Beijing Shifang Biotechnology Co., Ltd.). Straw decomposing agent dosage was $1.5 \mathrm{~kg} \cdot \mathrm{hm}^{-2}$, diluted with water 100 times, and the effective viable bacteria number was $\geqslant 50$ million $\cdot \mathrm{g}^{-1}$.

Sampling and Analysis Methods. On the 15th, 35th, 55th, 75th, 95th, 145th and 365th day after the nylon net bags were placed in the field plots, 3 bags were randomly sampled from each plot. For each net bag, we first washed the surface soil off with tap water, then washed the sample with distilled water 3 times, dried it at $60^{\circ} \mathrm{C}$, weighed it and then ground it to deter-mine the decomposition rate of straw and its components. At the same time, $200 \mathrm{~g}$ of soil from each soil bag was taken for the determination of soil SOC, MBC and DOC. Content of cellulose, hemicellulose and lignin in straw were determined following 
Van's method ${ }^{27}$, using a SLQ-6A semi-automatic crude fiber analyzer (Shanghai Fiber Testing Instrument Co., Ltd.).

The following formula was used to calculate decomposition rate of straw and its components. $M_{0}$ is the initial straw or cellulose (hemicellulose, lignin) mass, g, and $M_{t}$ is the straw or cellulose (hemicellulose, lignin) mass at time $t, g$.

Decomposition proportion $(\%)=\frac{M_{0}-M_{t}}{M_{0}} \times 100$

The following formula was used to calculate the straw carbon release proportion. $C_{0}$ is the initial straw carbon content, $\mathrm{g}, C_{t}$ is the straw carbon content at time $\mathrm{t}, \mathrm{g}$.

Straw carbon release proportion $(\%)=\frac{C_{0}-C_{t}}{C_{0}} \times 100$

The following formula was used to calculate the straw and its components decomposition rate. $M_{365}$ is the quality of straw or cellulose (hemicellulose, lignin) mass on the 365 th day, $\mathrm{mg} \cdot \mathrm{d}^{-1}$.

Decomposition rate $\left(\mathrm{mg} \cdot \mathrm{d}^{-1}\right)=\frac{M_{0}-M_{365}}{365}$

The relationship of the straw decomposition proportion(\%) changes over time was fitted as follows:

$y_{t}=a+b \times \exp (-k t)$

where $y_{t}$ is the proportion of the straw decomposition proportion at time $t, \% ; \mathrm{t}$ is the decomposition time of straw; $k$ is the decomposition rate constant calculated using the least-squares method; $a$ and $b$ are constants.

SOC concentrations $\left(\mathrm{g} \cdot \mathrm{kg}^{-1}\right)$ was determined using the $\mathrm{K}_{2} \mathrm{Cr}_{2} \mathrm{O}_{7}-\mathrm{H}_{2} \mathrm{SO}_{4}$ digestion method ${ }^{28}$. Soil MBC content was determined using the Chloroform fumigation extraction method ${ }^{29}$. Two fresh soil samples were weighed, and then one of them was placed in a vacuum dryer with chloroform added, and pumped until the chloroform boiled violently, and after a period of time, the dryer cover was opened, the container containing chloroform removed, and the lid replaced. Another portion of soil was placed in a vacuum dryer without chloroform as a control. Then, $20 \mathrm{~g}$ each of fumigated and unfumigated soil samples were weighed, $50 \mathrm{~mL} 0.5 \mathrm{mg} \cdot \mathrm{L}^{-1} \mathrm{~K}_{2} \mathrm{SO}_{4}$ was added, extracted by vibration for $0.5 \mathrm{~h}$, filtrate was pumped by $0.45 \mu \mathrm{m}$ organic filter membrane, and then the filtrate was directly analyzed and detected using a TOC organic carbon analyzer. Based on the difference of organic $\mathrm{C}$ content between fumigated and unfumigated soil extracts, the microbial biomass carbon was obtained by multiplying the coefficient by 2.64. For the determination of soil DOC content, we used a slightly modified method of Jones ${ }^{30}$ and $\mathrm{Hu}$ Haiqing ${ }^{31}$. We made a leaching solution with $0.5 \mathrm{~mol} \cdot \mathrm{L} \mathrm{K}_{2} \mathrm{SO}_{4}$, weighed $10 \mathrm{~g}$ over $2 \mathrm{~mm}$ sieve of air dried soil, added the soil to the leaching solution to create a soil mass ratio of 2.5:1, and then applied a shock temperature for $1 \mathrm{~h}\left(220 \mathrm{r} \cdot \mathrm{min}^{-1}\right)$. Then, after filtering, the filtrate was centrifuged for $20 \mathrm{~min}(3800$ $\mathrm{r} \cdot \mathrm{min}^{-1}$ ), filtered with a $0.45 \mu \mathrm{m}$ organic membrane, and the filtrate subjected to TOC organic carbon analysis meter tests.

Data analysis. In this experiment, Excel 2016 (Microsoft Corporation, New Mexico, USA) software was used to collate and analyze the data, and SPSS 19.0 (SPSS Inc., Chicago, Illinois, USA) statistical software was used to conduct variance analysis, LSD multiple analysis comparison and nonlinear regression analysis on the data. Duncan's multiple range test was used to compare the treatment means at a 95\% confidence level. Graphs were drawn using Origin 9.0 (Originlab, Northampton, USA). 


\section{Results}

Decomposition of straw and its components. From May to September 2019, the temperature and rainfall were higher, than from September 2019 to May 2020 (Fig. 1), and under the influence of temperature and moisture, the straw decomposition proportion in the early period was higher (0-95 days, 11.35-62.70\%), while at the late stage it was lower (95-356 days, 42.35-73.25\%, Fig. 2a). The decomposition proportion of straw and its organic components were higher for tillage than no-tillage mulching (Table 2). Moreover, decomposition proportion for rotary tillage was higher than deep turning + deep rotary tillage. At 365 days, the straw decomposition proportion under no-tillage mulching was $50.25-52.35 \%$, under deep turning + deep rotary tillage $61.90-66.90 \%$, and under rotary tillage $70.55-$ $73.25 \%$ treatments, respectively.

The first-order kinetic curve was used to fit the straw decomposition decomposition line chart (Fig. $2 \mathrm{~b}$ ), it was found that the fitting degree of each treatment was good. It took 291.5 days, 148 days, 90.3 days, 74 days, 64.5 days and 60.4 days for NT, NT $+\mathrm{S}, \mathrm{PT}, \mathrm{PT}+\mathrm{S}, \mathrm{RT}$ and $\mathrm{RT}+\mathrm{S}$ to decompose the straw to $50 \%$, respectively.

Under the same tillage method, the addition of decomposing agent promoted straw decomposition over the entire experiment, but its influence did not exceed the influence of tillage. The decomposition of cellulose, hemicellulose, and lignin in the straw was consistent with that of the straw, and straw decomposition proportion under deep turning + deep rotary tillage and rotary tillage was higher than that under no-tillage mulching. Under the same tillage pattern, the decomposition proportion of straw organic components treated with decomposition agent was significantly higher than that without it. At $365 \mathrm{~d}$, the lignin decomposition proportion was lower than that of cellulose and hemicellulose. The decomposition proportion of lignin, cellulose and hemicellulose were $27.14-36.89 \%, 56.56-85.53 \%$ and $64.17-86.50 \%$, respectively. The straw and cellulose and hemicellulose decomposition proportion under rotary tillage and deep turning + deep rotary tillage were higher than those under no-tillage mulching (Table 2, Fig. 3 ).
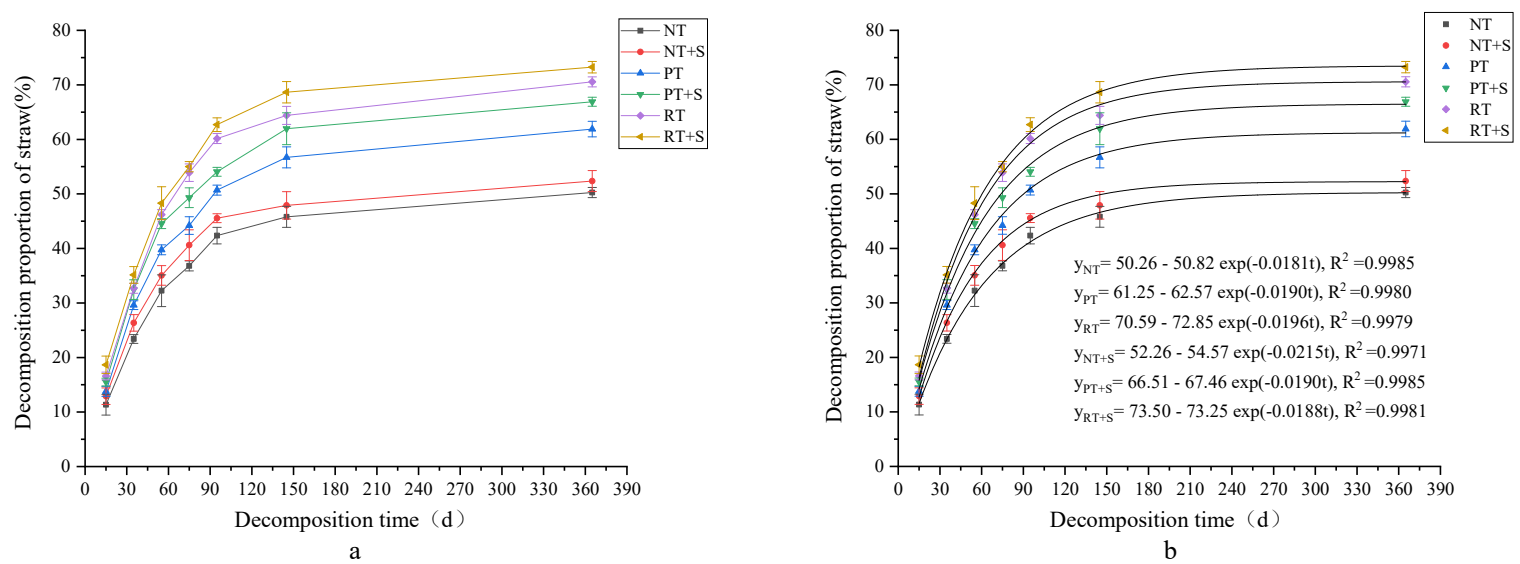

Figure 2. a, Straw decomposition proportion original curve; $\mathbf{b}$, Fitting curve by using the first order dynamic equation. $\mathrm{NT}=$ no-tillage mulching and straw return to the field + no straw decomposing agent; $\mathrm{NT}+\mathrm{S}=$ no-tillage mulching and straw return to the field + straw decomposing agent; $\mathrm{PT}=$ deep turning + deep rotary tillage + no straw decomposing agent; $\mathrm{PT}+\mathrm{S}=$ deep turning + deep rotary tillage + straw decomposing agent; $\mathrm{RT}=$ rotating tillage + no straw decomposing agent; $\mathrm{RT}+\mathrm{S}=$ rotating tillage + straw decomposing agent. The same below. 


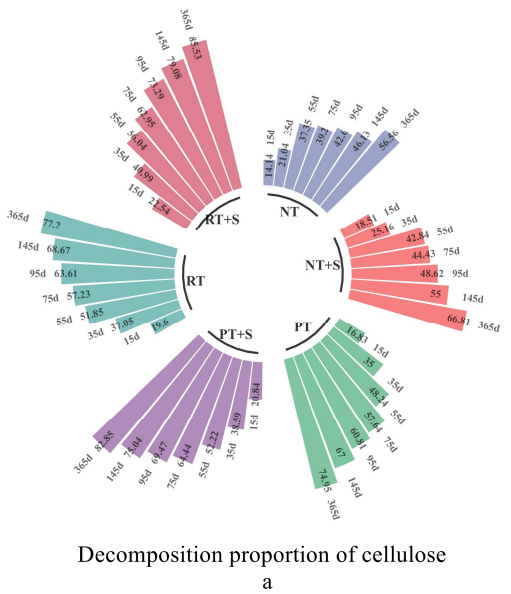

a

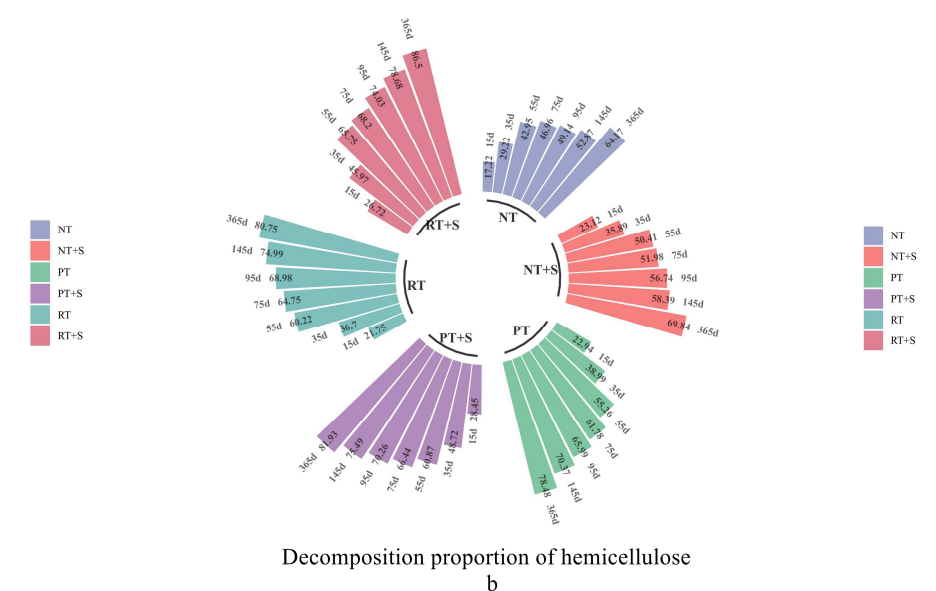

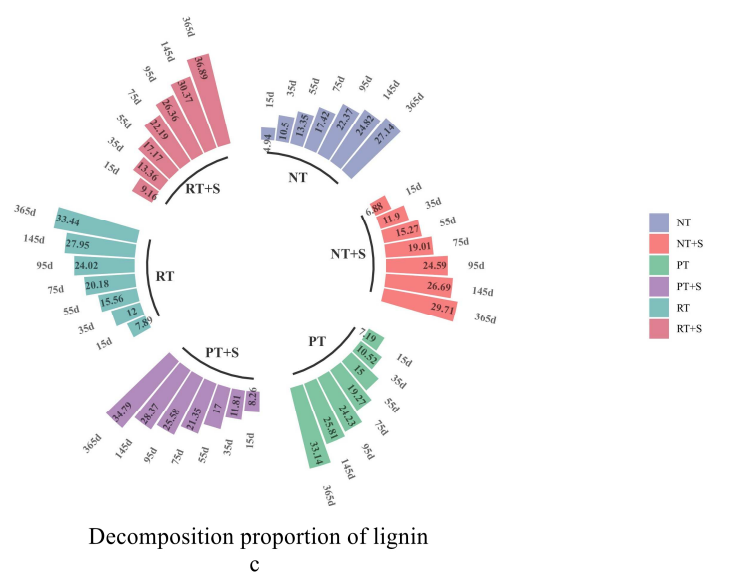

Figure 3. a, b, c are the circular barplots of the decomposition proportion of cellulose, hemicellulose and lignin in straw at $15,35,55,75,95,145$ and 365 days.

Straw carbon release. Trends in straw carbon release proportion and straw decomposition proportion were basically the same, being initially fast, and slow in later stages. Average carbon release proportion of straw under rotary tillage mode was higher than under the other two tillage treatments. Carbon release rates of straw between the three treatments was as follows: rotary tillage $>$ deep turning + deep rotary tillage $>$ no-tillage (Table 2). At 365 days, the carbon release proportion of each treated straw was $49.44-71.05 \%$. For the same return method, adding straw decomposition agent promoted carbon release. $\mathrm{RT}+\mathrm{S}$ treatment had the highest proportion of straw carbon release in each time period among different return methods (Fig. 4a)

First-order dynamics curve was used to fit the straw carbon release proportion line chart(Fig. $4 \mathrm{~b}$ ). The time for $\mathrm{NT}+\mathrm{S}, \mathrm{PT}, \mathrm{PT}+\mathrm{S}, \mathrm{RT}$ and $\mathrm{RT}+\mathrm{S}$ treatments to release $50 \%$ of straw carbon was 152 days, 93 days, 73.7 days, 59 days and 58.8 days, respectively. It is worth mentioning that the straw carbon release proportion of NT treatment did not reach 50\% within 365 days. 


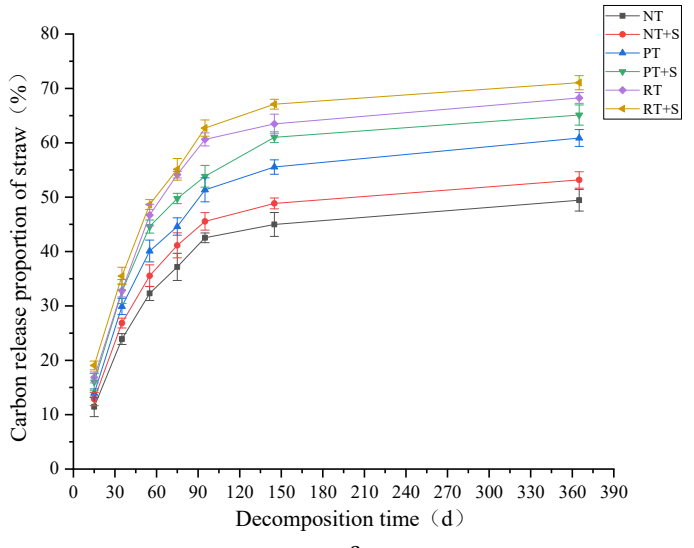

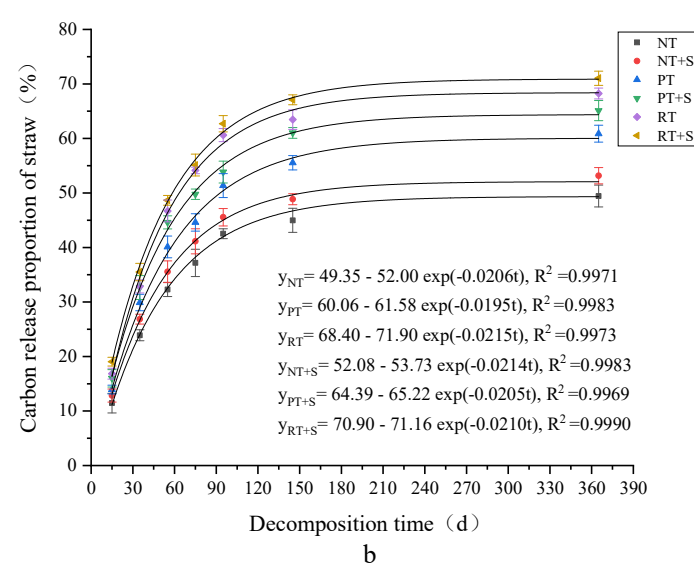

Figure 4. a, Straw carbon release proportion original curve; $\mathbf{b}$, Fitting curve by using the first order dynamic equation.

Table 2. Straw decomposition and carbon release rates under different return methods. F: Methods of returning farmland; Tr: processing. Different letters after the mean indicate a significant difference between treatments. $* * *$ and $* * *$ indicate a significance difference at $0.05,0.01$ and 0.001 levels, respectively. NS means no significant difference.

\begin{tabular}{|c|c|c|c|c|c|c|}
\hline Treatment & $\begin{array}{c}\text { Farming } \\
\text { method }\end{array}$ & $\begin{array}{c}\text { Straw } \\
\text { decomposition } \\
\text { rate }\left(\mathrm{mg}^{\prime} \cdot \mathrm{d}^{-1}\right)\end{array}$ & $\begin{array}{c}\text { Cellulose } \\
\text { decomposition } \\
\text { rate }\left(\mathrm{mg} \cdot \mathrm{d}^{-1}\right)\end{array}$ & $\begin{array}{c}\text { Hemicellulose } \\
\text { decomposition } \\
\text { rate }\left(\mathrm{mg} \cdot \mathrm{d}^{-1}\right)\end{array}$ & $\begin{array}{c}\text { Lignin } \\
\text { decomposition } \\
\text { rate }\left(\mathrm{mg} \cdot \mathrm{d}^{-1}\right)\end{array}$ & $\begin{array}{c}\mathrm{C} \text { releasing rate } \\
\left(\mathrm{mg} \cdot \mathrm{d}^{-1}\right)\end{array}$ \\
\hline \multirow{3}{*}{$\begin{array}{c}\text { No } \\
\text { decomposi } \\
\text { ng agent }\end{array}$} & NT & $13.8 \pm 0.10 \mathrm{c}$ & $4.7 \pm 0.10 \mathrm{~b}$ & $6.0 \pm 0.20 \mathrm{~b}$ & $0.8 \pm 0.01 \mathrm{c}$ & $3.6 \pm 0.02 \mathrm{c}$ \\
\hline & PT & $17.0 \pm 0.04 \mathrm{~b}$ & $6.5 \pm 0.08 \mathrm{a}$ & $7.4 \pm 0.20 \mathrm{a}$ & $0.9 \pm 0.01 \mathrm{~b}$ & $6.2 \pm 0.05 \mathrm{~b}$ \\
\hline & RT & $19.3 \pm 0.06 \mathrm{a}$ & $6.6 \pm 0.10 \mathrm{a}$ & $7.5 \pm 0.10 \mathrm{a}$ & $2.1 \pm 0.03 \mathrm{a}$ & $6.9 \pm 0.07 \mathrm{a}$ \\
\hline \multirow{3}{*}{$\begin{array}{c}\text { Decomposi } \\
\text { ng agent }\end{array}$} & NT & $14.4 \pm 0.02 \mathrm{c}$ & $5.7 \pm 0.20 \mathrm{~b}$ & $6.6 \pm 0.10 \mathrm{~b}$ & $0.8 \pm 0.02 \mathrm{c}$ & $5.17 \pm 0.08 \mathrm{c}$ \\
\hline & PT & $18.3 \pm 0.30 \mathrm{~b}$ & $7.4 \pm 0.10 \mathrm{a}$ & $8.1 \pm 0.20 \mathrm{a}$ & $1.0 \pm 0.02 \mathrm{~b}$ & $6.6 \pm 0.10 \mathrm{~b}$ \\
\hline & RT & $20.1 \pm 0.20 \mathrm{a}$ & $7.4 \pm 0.03 \mathrm{a}$ & $8.1 \pm 0.30 \mathrm{a}$ & $2.4 \pm 0.07 \mathrm{a}$ & $7.17 \pm 0.80 \mathrm{a}$ \\
\hline \multicolumn{2}{|c|}{$\mathbf{F}$} & $32.6^{* * *}$ & $4.1^{* * *}$ & $2.8 * * *$ & $2.6^{* * *}$ & $4.0 * * *$ \\
\hline \multicolumn{2}{|c|}{$\operatorname{Tr}$} & $2.4^{* * *}$ & $2.2 * * *$ & $1.1^{* *}$ & $0.04 * * *$ & $0.3 * * *$ \\
\hline \multicolumn{2}{|c|}{$\mathbf{F} \times \mathbf{T r}$} & $0.176^{*}$ & 0.01 & 0.009 & $0.009 * * *$ & NS \\
\hline
\end{tabular}

Dynamic changes in soil organic carbon and soil microbial biomass carbon. On the 35 th to 55th day after straw return, SOC content of each treatment decreased gradually, and reached $11.27-12.13 \mathrm{~g} \cdot \mathrm{kg}^{-}$ ${ }^{1}$ on the 55 th day. From $55 \mathrm{~d}$ to $95 \mathrm{~d}$, SOC content changes were consistent with straw carbon release proportion, which showed a rapid increase. $\mathrm{RT}+\mathrm{S}$ treatment SOC content was higher than other treatments on the 95th day $\left(17.51 \mathrm{~g} \cdot \mathrm{kg}^{-1}\right)$, and remained at the highest level of all treatments until maize harvest time

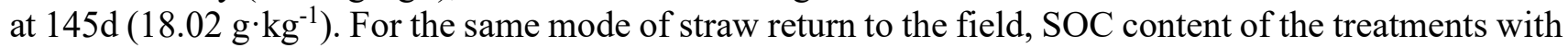
the addition of decomposing agent significantly higher than without it (Fig. 5).

Overall MBC content changes were consistent with those for SOC, that is, initial decline from the 35 th day after straw return to the field, and then increasing from the 55th day, and remaining at a higher level for a long time. From $35 \mathrm{~d}$ to $145 \mathrm{~d}, \mathrm{PT}+\mathrm{S}$ and $\mathrm{RT}+\mathrm{S}$ treatment $\mathrm{MBC}$ content was always at the highest level and higher than other treatments, but there was no significant difference between the two treatments. NT treatment MBC content was lower than in other treatments. Under the same return method, MBC content in the treatments with straw decomposing agent were higher than those without it(Fig. 5). 

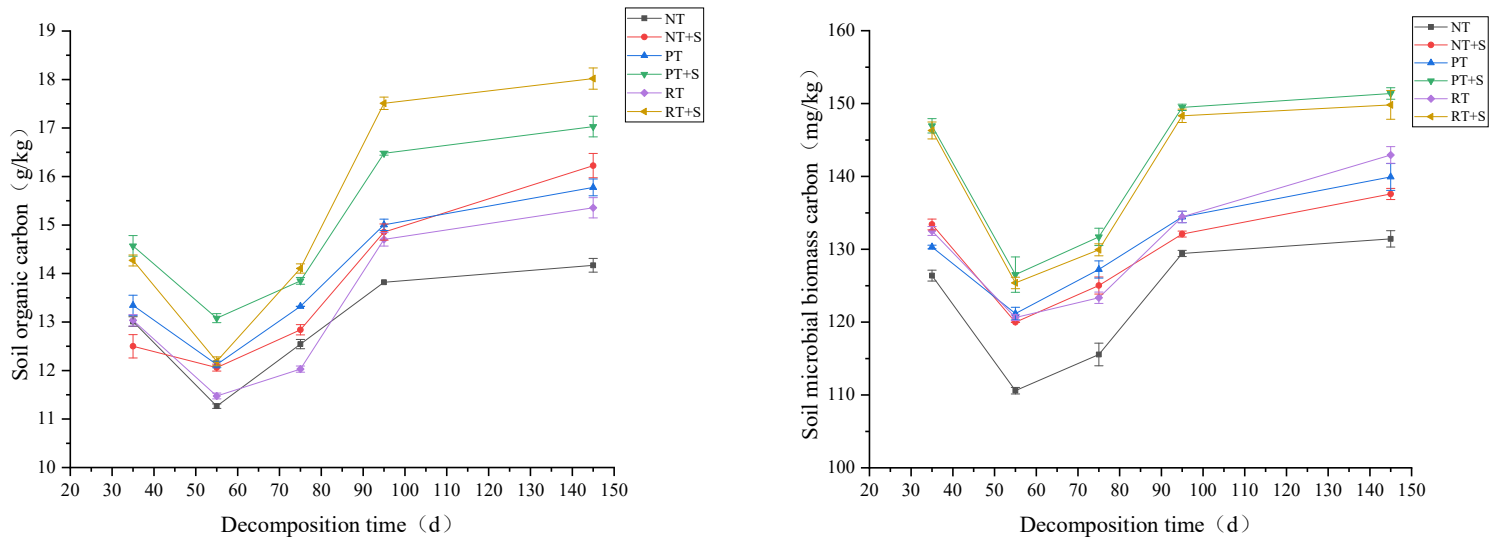

Figure 5. Changes of soil organic carbon and microbial biomass carbon under different returning modes.

Changes in soil soluble organic carbon. Generally, both the straw return method and the decaying agent had effects on soil DOC content: rotary tillage $>$ deep turning + deep rotary tillage $>$ no-tillage; and straw decomposing agent addition $>$ no straw decomposing agent. After straw was returned to the field, soil DOC content of all treatments increased rapidly with the rapid decomposition of straw and release of straw carbon, reaching a maximum of $114.29-135.29 \mathrm{mg} \cdot \mathrm{kg}^{-1}$ on the 95 th day. From $95 \mathrm{~d}$ to $145 \mathrm{~d}$, soil DOC content of all treatments began to decrease gradually. During the $35 \mathrm{~d}$ to $145 \mathrm{~d}$ decay period, soil $\mathrm{DOC}$ content in $\mathrm{RT}+\mathrm{S}$ and $\mathrm{PT}+\mathrm{S}$ treatments was generally at a higher level, and $\mathrm{RT}+\mathrm{S}$ was higher, than other treatments. NT treatment soil DOC content was always the lowest, and the soil DOC content of $\mathrm{NT}+\mathrm{S}$ increased (Fig. 6).

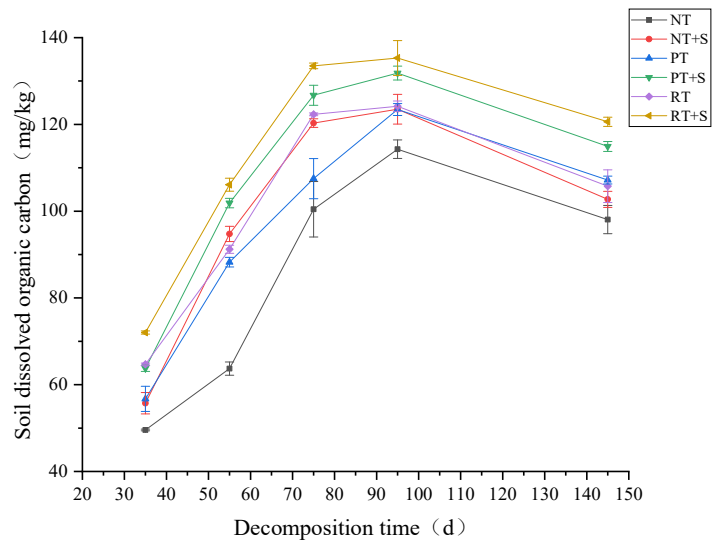

Figure 6. Changes of soil soluble organic carbon under different returning modes.

\section{Discussion}

Effects of returning methods and climate on straw decomposition. The straw decomposition process is affected by air temperature and precipitation, decomposition and nutrient release of returned maize straw requires optimum temperature and soil moisture conditions ${ }^{32,33}$. Studies have shown that in the early stage of field return, non-structural and easily decomposed substances such as soluble carbohydrates, organic acids and amino acids are released rapidly, providing a large number of carbon sources and nutrients for soil microorganisms, increasing their numbers, and enhancing their activity, thus accelerating the decomposition of straw organic components ${ }^{34}$. In our experiment, with increasing temperature and rainfall for the $0-95 \mathrm{~d}$ after straw return to the field, overall decomposition proportion, carbon release proportion and cellulose, hemicellulose, and lignin decomposition proportion of all 
treatments were similar, that is, they increased rapidly (Fig. 1), our finding was consistent with the work of Yang et $\mathrm{al}^{35}$. During the $95 \mathrm{~d}-145 \mathrm{~d}$ period, a drop in temperature and precipitation occurs, microbial decomposition activity slows down, due to the perishable nature of straw, components such as cellulose and hemicellulose gradually decline, refractory organic components such as lignin proportion increase, so straw decomposition gradually slows, and late decomposition proportion is significantly reduced ${ }^{36}$. Under different tillage methods, the soil layer of returned straw varies, and the soil temperature, water and oxygen content are also different, which further affects soil microbiology characteristics and straw decomposition rate $^{23}$. In this study, the straw decomposition rate of the two treatments of overburying and returning to the field was significantly higher than that of the no-tillage mulching treatment. This was because the straw was fully mixed with the soil, which was conducive to microbial decomposition, making full use of soil moisture and nutrients, promoting straw decomposition ${ }^{37}$. Under no-tillage mulching, straw is exposed to the air and not in full contact with soil and water, the decomposing agent is exposed to the ground, and microorganisms are unable to play a role, thus affecting straw decomposition. Studies have shown that under no-tillage mulching, the microbial activity was low, however, biodegradation is the main driver of straw decomposition under wet soil conditions ${ }^{38}$. In deep turning + deep rotary tillage treatments, some straw is about $30 \mathrm{~cm}$ below the soil surface, and organic materials tend to decompose anaerobically at this depth. Our results showed that an aerobic environment was beneficial to crop straw degradation, while anaerobic conditions inhibited aerobic soil microorganism activity under similar soil moisture content ${ }^{15}$. Under anaerobic conditions, the relative content of refractory components such as lignin in crop straw increased, which reduced straw degradation rate $^{39}$. Straw return depth under rotary tillage was relatively shallow, it is more easily exposed to oxygen, so straw decomposition rate was higher than under deep turning + deep rotary tillage.

Effects of return method and decomposing agent on soil carbon form dynamics. From $35 \mathrm{~d}$ to $55 \mathrm{~d}$ after straw returning, the contents of MBC and SOC in soil decreased and were the lowest in the whole period at $55 \mathrm{~d}$. This is because the addition of exogenous organic matter stimulates the original organic matter in the soil, promoting the decomposition of soil organic carbon ${ }^{40}$, which results in the decrease of soil organic carbon content at this stage. During this process, soil microorganisms also need abundant nitrogen to meet their reproductive needs. At this time, the maize jointing stage is at the peak of nitrogen absorption, and the $\mathrm{C} / \mathrm{N}$ ratio increases significantly, which inhibits the reproduction of microorganisms, leading to a decrease of soil microbial biomass carbon content ${ }^{41}$. In straw return after 55d-95d, temperature and precipitation are at their annual maximum(Fig. 1), which can enhance microorganism diversity and activity, and improve straw decomposition proportion, thus improving straw carbon release proportion, significantly increasing the distribution of soil organic carbon soil, and rapidly increasing soil MBC and total organic carbon content ${ }^{17,42}$. Spedding ${ }^{43}$ found that the soil MBC of straw returned to the field increased by $61 \%$ compared with that of non-return. After 95 days of straw return to the field, straw decomposition proportion gradually slowed down, and the MBC and total organic carbon content tended to be stable. On the 95d, the order of SOC content of each treatment from high to low was $\mathrm{RT}+\mathrm{S}, \mathrm{PT}+\mathrm{S}, \mathrm{NT}+\mathrm{S}, \mathrm{PT}, \mathrm{RT}, \mathrm{NT}$, indicating that decomposing agent addition significantly improved SOC, and rotating tillage combined with decomposing agent had the most improved SOC content. The effects of straw return on SOC and carbon forms are affected by many factors, such as soil moisture, temperature and biochemical characteristics, which differ depending on the method of straw return and soil depth ${ }^{44}$. The trend in soil DOC content was consistent with straw decomposition rate 35 to 95 days after straw return, but after 95 days, with the straw decomposition proportion and straw carbon release became slow, temperature and rainfall became slow, the content of soil DOC decreases accordingly. In the RT $+\mathrm{S}$ treatment from $35 \mathrm{~d}$ to $95 \mathrm{~d}$, DOC content was significantly higher than in other treatments, followed by $\mathrm{PT}+\mathrm{S}$ treatment. The accumulation effect of SOC, DOC and MBC contents under rotary tillage and deep turning + deep rotary tillage was better than that under no-tillage mulch. Correlative studies also showed that treatments with added decomposing agent significantly increased soil active organic carbon, MBC and $\mathrm{DOC}^{45}$. Straw decomposing agent is rich in microorganisms such as cellulose, hemicellulose and 
lignin-degrading bacteria, which can increase the diversity, activity and quantity of soil microbial community structure, and thus accelerate the decomposition process of straw components ${ }^{46}$. Therefore, to accelerate the decomposition process of returned straw and improve the decomposition proportion of its organic components, straw decomposing agent can be added at the same time as the straw.

\section{Conclusion}

Among the three returning models, rotary tillage and deep turning + deep rotary tillage had better effect on straw decomposition and carbon release proportion of returning straw than no tillage. This conclusion can also be verified by calculating the half-life of straw decomposition proportion and carbon release proportion through the fitting curve of the first-order dynamic equation. $\mathrm{RT}+\mathrm{S}$ treatment had the highest proportion of straw decomposition and straw carbon release in each sampling period. In each sampling period of 95d-365d, the decomposition proportion of cellulose, hemicellulose and lignin in $\mathrm{RT}+\mathrm{S}$ treatment was the highest. The SOC content of various forms were significantly increased with the $\mathrm{RT}+\mathrm{S}$ treatment. On the $145 \mathrm{~d}$, the contents of DOC and SOC in RT $+\mathrm{S}$ treatment were the highest, and $\mathrm{MBC}$ content was lower than that in $\mathrm{PT}+\mathrm{S}$ treatment and higher than other treatments. Under the same return method, straw decomposition proportion, straw organic component decomposition proportion, and straw treated with decomposing agent carbon release proportion were all higher than treatments without decomposing agent. SOC, DOC and MBC contents in the treatments with added decomposing agent were higher than in treatments without it. in the short term, in order to speed up the decomposition rate of returning straw and improve the content of various forms of soil carbon, rotary tillage returning mode can be adopted, and the straw decomposition agent can be sprayed on the surface of returning straw at the same time. ${ }^{1}$

\section{References}

1. Bi, Y., Wang, Y. \& Gao, C. Straw Resource Quantity and its Regional Distribution in China. Journal of Agricultural Mechanization Research, DOI: https://doi.org/10.13427/j.cnki.njyi.2010.03.031 (2010).

2. Fu \& B. Blue Skies for China. Science 321, 611, DOI: https://doi.org/10.1126/science.1162213 (2008).

3. Liu, T., He, G. \& Lau, A. Statistical evidence on the impact of agricultural straw burning on urban air quality in China. Science of The Total Environment 711, 134633, DOI: https://doi.org/10.1016/j.scitote nv.2019.134633 (2019).

4. Jiajiang et al. The effects of different types of crop straw on the transformation of pentachlorophenol in flooded paddy soil. ENVIRONMENTAL POLLUTION 233, 745-754, DOI: https://doi.org/10.1016/j.env pol.2017.10.114 (2018).

5. Lugato, E., Berti, A. \& Giardini, L. Soil organic carbon (SOC) dynamics with and without residue inco rporation in relation to different nitrogen fertilisation rates. Geoderma 135, 315-321, DOI: https://doi.or g/10.1016/j.geoderma.2006.01.012 (2006).

6. Yan, X., Akiyama, H., Yagi, K. \& Akimoto, H. Global estimations of the inventory and mitigation pote ntial of methane emissions from rice cultivation conducted using the 2006 Intergovernmental Panel on Climate Change Guidelines. Glob.biogeochem.cycles 23, - , DOI: https://doi.org/10.1029/2008GB00329 9 (2009).

7. Zhang, P. et al. Effects of straw incorporation on the stratification of the soil organic $\mathrm{C}$, total $\mathrm{N}$ and C:N ratio in a semiarid region of China. Soil and Tillage Research, DOI: https://doi.org/10.1016/j.still.2 015.04.008 (2015).

8. Puttaso, A., Vityakon, P., Saenjan, P., Trelo-Ges, V. \& Cadisch, G. Relationship between residue qua lity, decomposition patterns, and soil organic matter accumulation in a tropical sandy soil after 13 yea rs. Nutrient Cycling in Agroecosystems 89, 159-174, DOI: https://doi.org/10.1007/s10705-010-9385-1 (2 011). 
9. Latifmanesh, H. et al. Integrative impacts of rotational tillage on wheat yield and dry matter accumula tion under corn-wheat cropping system. Soil \& Tillage Research 184, DOI: https://doi.org/10.1016/j.still. 2018.07.008 (2018).

10. Latifmanesh, $\mathrm{H}$. et al. Integrative impacts of soil tillage on crop yield, $\mathrm{N}$ use efficiency and greenhous e gas emission in wheat-corn cropping system. International Journal of Plant Production 10, 317-333, DOI: https://doi.org/10(3):317-334 (2016).

11. Tangyuan, N., Bin, H., Nianyuan, J., Shenzhong, T. \& Zengjia, L. Effects of conservation tillage on $s$ oil porosity in maize-wheat cropping system. Plant Soil \& Environment 55, 327-333, DOI: https://doi.or g/10.1111/j.1365-3059.2009.02047.x (2009).

12. Muhammad, W., Vaughan, S. M., Dalal, R. C. \& Menzies, N. W. Crop residues and fertilizer nitrogen influence residue decomposition and nitrous oxide emission from a Vertisol. Biology and Fertility of Soils 47, DOI: https://doi.org/10.1007/s00374-010-0497-1 (2011).

13. Devêvre, O. C. \& Horwáth, W. R. Decomposition of rice straw and microbial carbon use efficiency un der different soil temperatures and moistures. Soil Biology and Biochemistry 32, DOI: https://doi.org/1 0.1016/S0038-0717(00)00096-1 (2000).

14. Huang, S., Sun, Y., Yu, X. \& Zhang, W. Interactive effects of temperature and moisture on $\mathrm{CO} 2$ and $\mathrm{CH} 4$ production in a paddy soil under long-term different fertilization regimes. Biology \& Fertility of $S$ oils 52, 285-294, DOI: https://doi.org/10.1007/s00374-015-1075-3 (2016).

15. Jia, X., Shao, M. a., Wei, X. \& Li, X. Response of soil CO 2 efflux to water addition in temperate $\mathrm{s}$ emiarid grassland in northern China: the importance of water availability and species composition. Bio logy and Fertility of Soils 50, DOI: https://doi.org/10.1007/s00374-014-0901-3 (2014).

16. Sain, P. \& Broadbent, F. E. Decomposition of Rice Straw in Soils as Affected by Some Management Factors. Journal of Environmental Quality 6, DOI: https://doi.org/10.2134/jeq1977.00472425000600010 021x (1977).

17. Zhang, G. et al. Effect of rice straw application on stable carbon isotopes, methanogenic pathway, an d fraction of $\mathrm{CH} 4$ oxidized in a continuously flooded rice field in winter season. Soil Biology \& Bioch emistry 84, 75-82, DOI: https://doi.org/10.1016/j.soilbio.2015.02.008 (2015).

18. Bayer, C., Mielniczuk, J., Amado, T., Martin-Neto, L. \& Fernandes, S. V. Organic matter storage in a sandy clay loam Acrisol affected by tillage and cropping systems in southern Brazil. Soil \& Tillage Re search 54, 101-109, DOI: https://doi.org/10.1016/S0167-1987(00)00090-8 (2000).

19. Bolliger, A., Magid, J., Amado, J., Neto, F. S. \& Neergaard, A. D. Taking Stock of the Brazilian "Zer o - Till Revolution": A Review of Landmark Research and Farmers' Practice. Advances in Agronomy 9 1, 47-110, DOI: https://doi.org/10.1016/S0065-2113(06)91002-5 (2006).

20. Calegari, A. et al. Impact of Long - Term No - Tillage and Cropping System Management on Soil Org anic Carbon in an Oxisol: A Model for Sustainability. Agronomy Journal 100, DOI: https://doi.org/10.21 34/agronj2007.0121 (2008).

21. Christensen, B. T. Barley straw decomposition under field conditions: Effect of placement and initial ni trogen content on weight loss and nitrogen dynamics. Soil Biology \& Biochemistry 18, 523-529, DOI: https://doi.org/10.1016/0038-0717(86)90010-6 (1986).

22. Douglas, C. L., Allmaras, R. R., Rasmussen, P. E., Ramig, R. E. \& Roager, N. C. Wheat Straw Co mposition and Placement Effects on Decomposition in Dryland Agriculture of the Pacific Northwest. $S$ oil Science Society of America Journal 44, DOI: https://doi.org/10.2136/sssaj1980.03615995004400040 035x (1980).

23. Latifmanesh, H., Deng, A., Li, L., Chen, Z. \& Zhang, W. How incorporation depth of corn straw affect $\mathrm{s}$ straw decomposition rate and C\&N release in the wheat-corn cropping system. Agriculture Ecosyste $m s$ \& Environment 300, 107000, DOI: https://doi.org/10.1016/j.agee.2020.107000 (2020).

24. Jiang, X., Chi, S., Yun, W., Ning, T. \& Li, Z. Effect of less tillage and no-tillage patterns on decomp osition of returned maize straw in wheat/maize system. Transactions of the Chinese Society of Agricu Itural Engineering 25, 247-251, DOI: https://doi.org/10.3969/j.issn.1002-6819.2009.10.045 (2009).

25. Swift, M. J., Heal, O. W. \& Anderson, J. M. Decomposition in terrestrial ecosystems. Studies in Ecol ogy 5, 2772-2774, DOI: https://doi.org/10.1063/1.1615673 (1979). 
26. Witt, C. et al. Crop rotation and residue management effects on carbon sequestration, nitrogen cyclin $\mathrm{g}$ and productivity of irrigated rice systems. Plant \& Soil 225, 263-278, DOI: https://doi.org/10.1046/j.1 365-2915.1998.00116.x (2000).

27. Soest, P. J. V. Use of detergents in the analysis of fibrous feeds. 2. A rapid method for the determi nation of fiber and lignin. Journal - Association of Official Analytical Chemists 49, 546-551, DOI: http s://doi.org/10.1093/jaoac/73.4.491 (1963).

28. Dikgwatlhe, S. B., Chen, Z. D., Lal, R., Zhang, H. L. \& Chen, F. Changes in soil organic carbon and nitrogen as affected by tillage and residue management under wheat-maize cropping system in the North China Plain. Soil \& Tillage Research 144, 110-118, DOI: https://doi.org/10.1016/j.still.2014.07.01 4 (2014).

29. Vance, E. D., Brookes, P. C. \& Jenkinson, D. S. An extraction method for measuring soil microbial b iomass C. Soil Biology and Biochemistry 19, 703-707, DOI: https://doi.org/10.1016/0038-0717(87)90052 $-6(1987)$.

30. Jones, DL, Willett \& VB. Experimental evaluation of methods to quantify dissolved organic nitrogen (D ON) and dissolved organic carbon (DOC) in soil. SOIL BIOL BIOCHEM 2006,38(5), 991-999, DOI: htt ps://doi.org/10.1016/j.soilbio.2005.08.012 (2006).

31. Hu, H., Xin, L. \& Long, S. Research Review on Soil Active Organic Carbon Fractionation and Analyti cal Methods. Forest Engineering, DOI: https://doi.org/10.16270/j.cnki.slgc.2012.05.026 (2012).

32. Gregorich, E. G. et al. Litter decay controlled by temperature, not soil properties, affecting future soil carbon. Global Change Biology, DOI: https://doi.org/10.1111/gcb.13502 (2016).

33. Wetterstedt, J. M., Persson, T. \& Gren, G. I. Temperature sensitivity and substrate quality in soil org anic matter decomposition: results of an incubation study with three substrates. Global Change Biolog y 16, DOI: https://doi.org/10.1111/j.1365-2486.2009.02112.x (2010).

34. Powell, J. R. et al. Effects of genetically modified, herbicide-tolerant crops and their management on soil food web properties and crop litter decomposition. Journal of Applied Ecology 46, 388-396, DOI: https://doi.org/10.1111/j.1365-2664.2009.01617.x (2009).

35. Yang, F. K., He, B., Zhang, L., Zhang, G. \& Gao, Y. An Approach to Improve Soil Quality: a Case Study of Straw Incorporation with a Decomposer Under Full Film-Mulched Ridge-Furrow Tillage on th e Semiarid Loess Plateau, China. Journal of Soil Science and Plant Nutrition 20, DOI: https://doi.org/ 10.1007/s42729-019-00106-y (2019).

36. Wang, X. B., Cai, D. X., Hoogmoed, W. B., Oenema, O. \& Perdok, U. D. Potential Effect of Conserv ation Tillage on Sustainable Land Use: A Review of Global Long-Term Studies. Pedosphere 16, 587595, DOI: https://doi.org/10.1016/S1002-0160(06)60092-1 (2006).

37. Lu, Y., Fu, L., Lu, Y., Hugenholtz, F. \& Ma, K. Effect of temperature on the structure and activity of a methanogenic archaeal community during rice straw decomposition. Soil Biology and Biochemistry, DOI: https://doi.org/10.1016/j.soilbio.2014.10.031 (2015).

38. Liu, S. et al. The role of UV-B radiation and precipitation on straw decomposition and topsoil C turno ver. Soil Biology and Biochemistry, DOI: https://doi.org/10.1016/j.soilbio.2014.06.009 (2014).

39. Wang, J., Chen, X. \& Wei, J. L. Decomposition of Rice Straw and Corn Straw Under Aerobic and A naerobic Conditions. Journal of Agricultural Resources and Environment, DOI: https://doi.org/10.13254/ j.jare.2016.0180 (2017).

40. Pan, Q. et al. Influences of 6-year Application of Biochar and Biochar-based Compound Fertilizer on Soil Bioactivity on Brown Soil. Acta Agriculturae Boreali-Sinica, DOI: https://doi.org/10.7668/hbnxb.2016. 03.033 (2016).

41. Hui-Jie, L. U., Hong-Bo, H. E., Zhang, X. D. \& Zheng, L. C. Dynamic of Amino Acid N in Different Grow Seasons of Maize in Different Management. Chinese Journal of Soil Science, DOI: https://doi.or g/10.19336/j.cnki.trtb.2012.01.007 (2012).

42. Chen, L. et al. Effects of straw amendment and moisture on microbial communities in Chinese fluvoaquic soil. Journal of Soils \& Sediments 14, 1829-1840, DOI: https://doi.org/10.1007/s11368-014-09242 (2014).

43. Spedding, T. A., Hamel, C., Mehuys, G. R. \& Madramootoo, C. A. Soil microbial dynamics in maizegrowing soil under different tillage and residue management systems. Soil Biology \& Biochemistry 36, 499-512, DOI: https://doi.org/10.1016/j.soilbio.2003.10.026 (2004). 
44. Balota, E. L., Calegari, A., Nakatani, A. S. \& Coyne, M. S. Benefits of winter cover crops and no-tilla ge for microbial parameters in a Brazilian Oxisol: A long-term study. Agriculture Ecosystems \& Enviro nment 197, 31-40, DOI: https://doi.org/10.1016/j.agee.2014.07.010 (2014).

45. Insam, H., Mitchell, C. C. \& Dormaar, J. F. Relationship of soil microbial biomass and activity with fe rtilization practice and crop yield of three ultisols. Soil Biology \& Biochemistry 23, 459-464, DOI: http s://doi.org/10.1016/0038-0717(91)90010-H (1991).

46. Yang, Z. X., Zhou, H. P., Guan, C. L., Xie, W. Y. \& Li, C. Effect of straw decomposing inoculant on maize straw returning. Journal of Shanxi Agricultural ences, DOI: https://doi.org/10.3969/j.issn.1002-24 81.2013.04.15 (2013).

\section{Author contributions statement}

Designed and performed most of the experiments, wrote the manuscript and analyzed the data, X.W., X.W. (Xuexin Wang),; helped with the data collection and analysis, K.C., P.G., Q.Y., N.L., Y.L(Yueling Fan)., X.Z. (Xiumei Zhan)., X.H. (Xiaori Han). All authors read and approved the manuscript.

\section{Additional information}

The authors declare no conflict of interest.

The experimental land is the public land of scientific research base of Shenyang Agricultural University in Anshan City, Liaoning Province, China.

\section{Funding}

The National Key Research and Development Plan of China, Shenyang, Project No. 2018YFD0300303. 

Figures

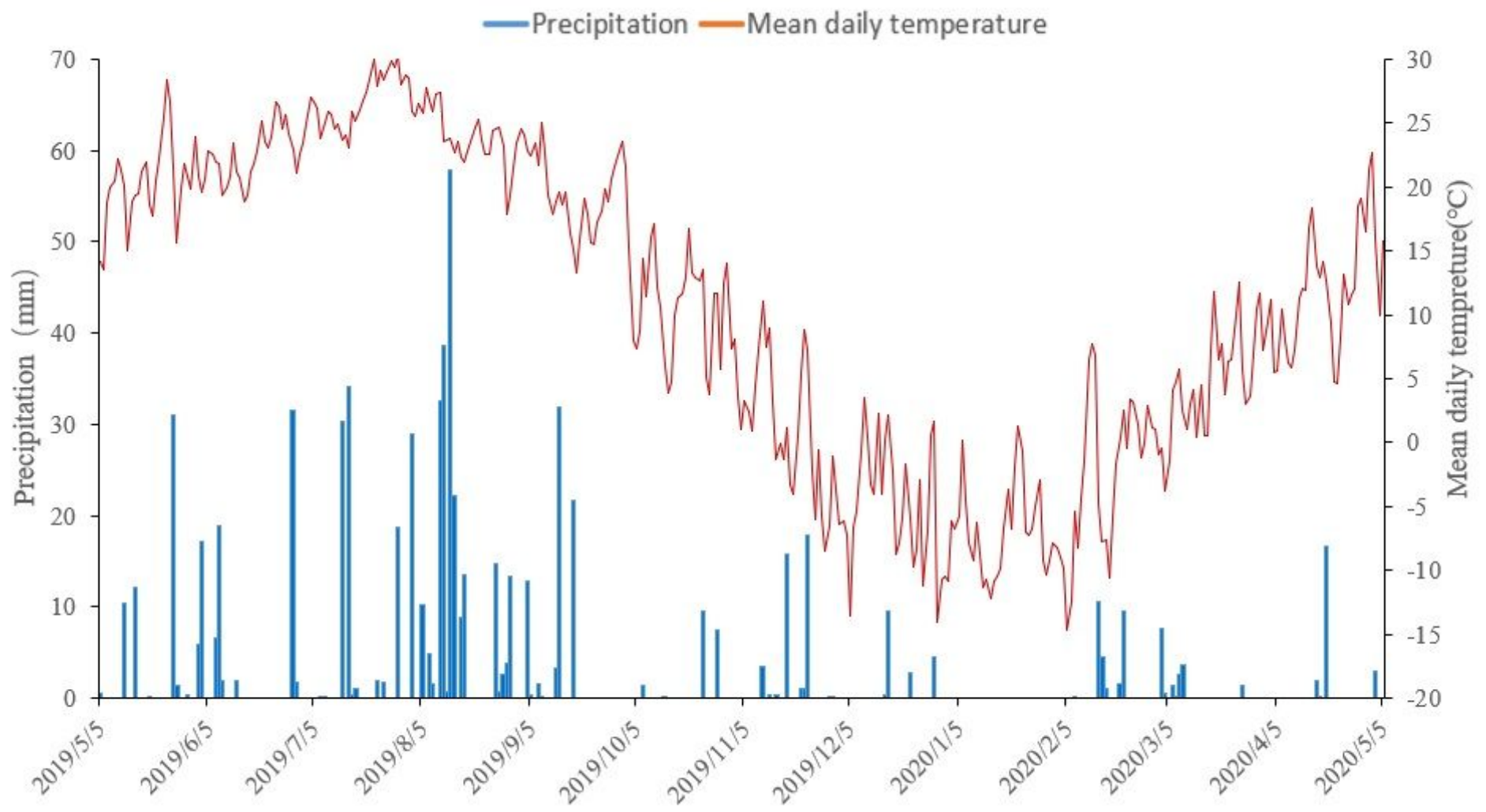

Figure 1

Daily precipitation and mean air temperature during the straw decomposition period from May 2019 to May 2020.

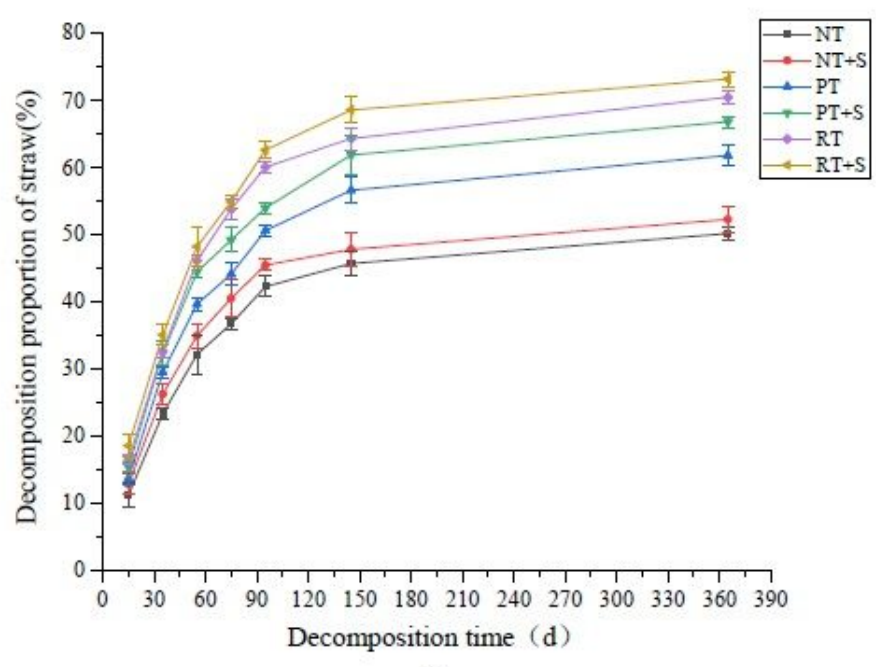

a

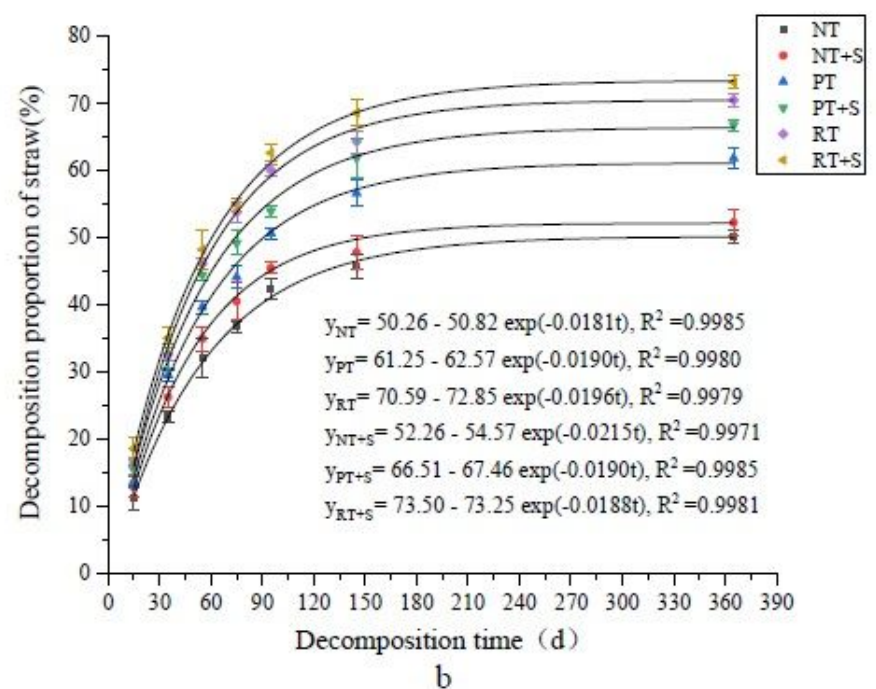

b

Figure 2 
a, Straw decomposition proportion original curve; $b$, Fitting curve by using the first order dynamic equation. NT = no-tillage mulching and straw return to the field + no straw decomposing agent; NT+S = no-tillage mulching and straw return to the field + straw decomposing agent; PT = deep turning + deep rotary tillage + no straw decomposing agent; $\mathrm{PT}+\mathrm{S}$ = deep turning + deep rotary tillage + straw decomposing agent; $\mathrm{RT}$ = rotating tillage + no straw decomposing agent; $\mathrm{RT}+\mathrm{S}=$ rotating tillage + straw decomposing agent. The same below.

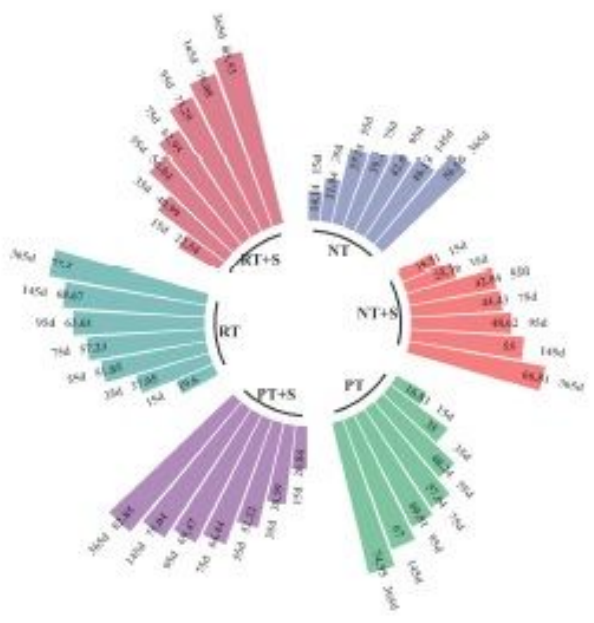

Decomposition proportion of cellulose

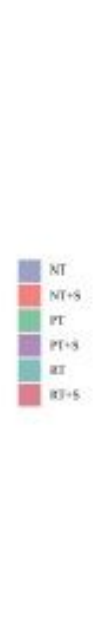

a

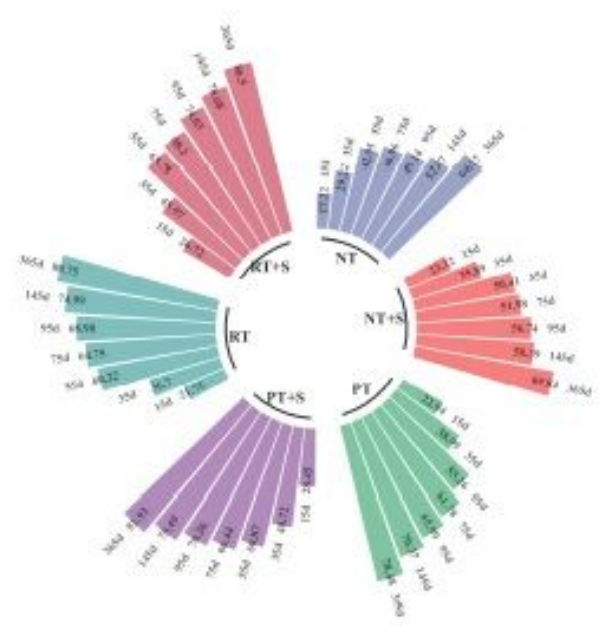

Decomposition proportion of hemicellulose

b

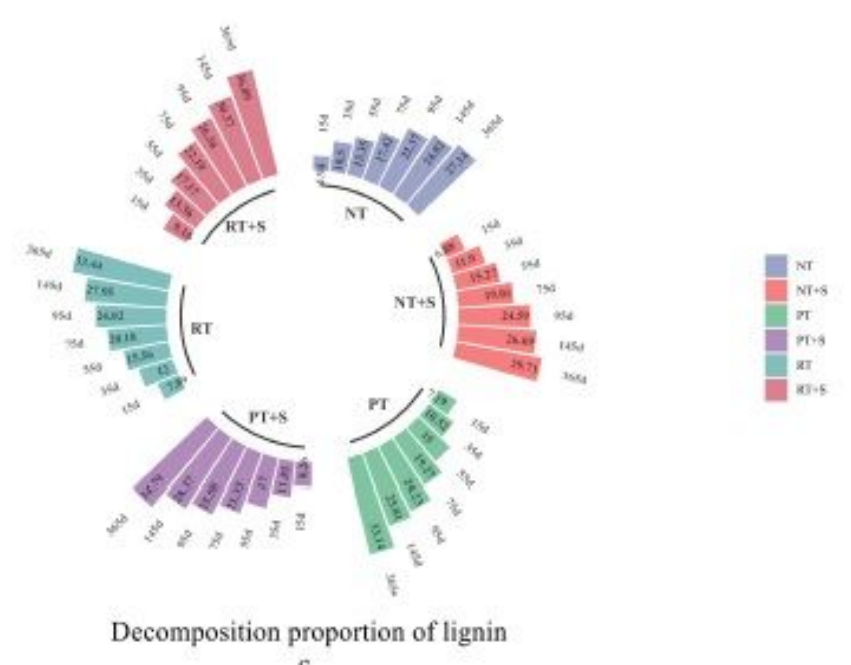

c

\section{Figure 3}

a, b, c are the circular barplots of the decomposition proportion of cellulose, hemicellulose and lignin in straw at $15,35,55,75,95,145$ and 365 days. 


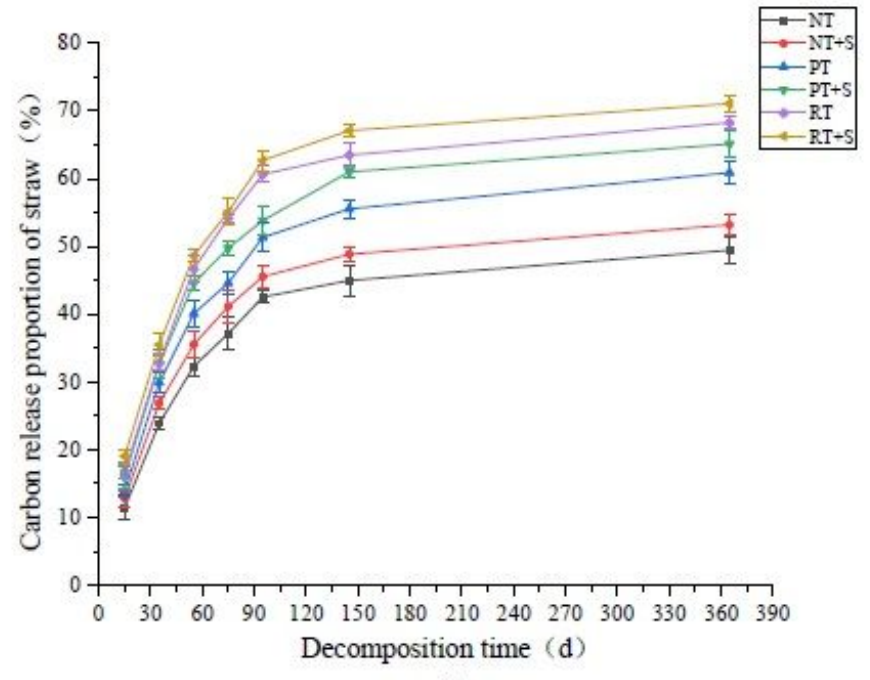

a

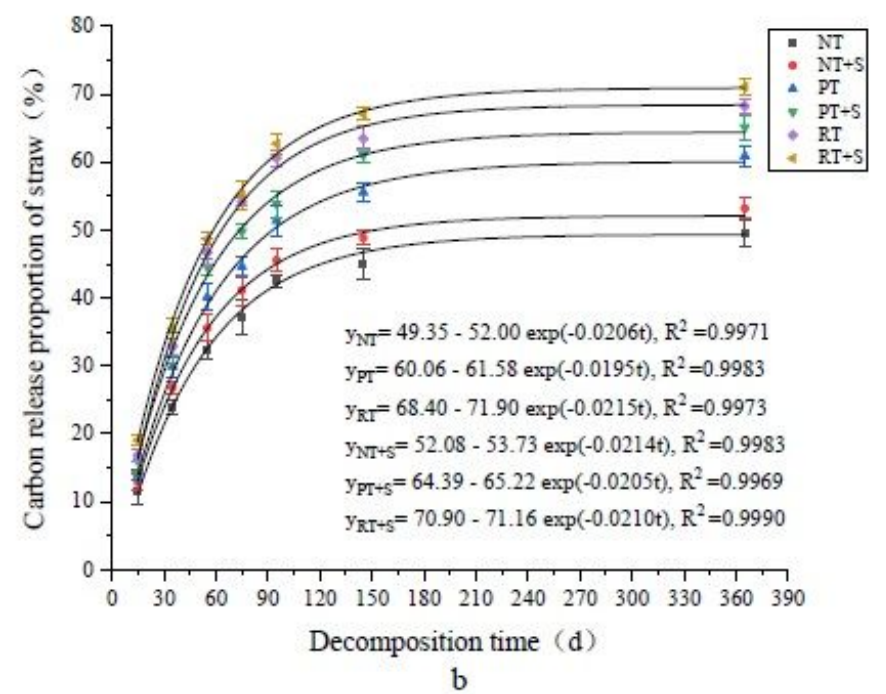

Figure 4

a, Straw carbon release proportion original curve; b, Fitting curve by using the first order dynamic equation.
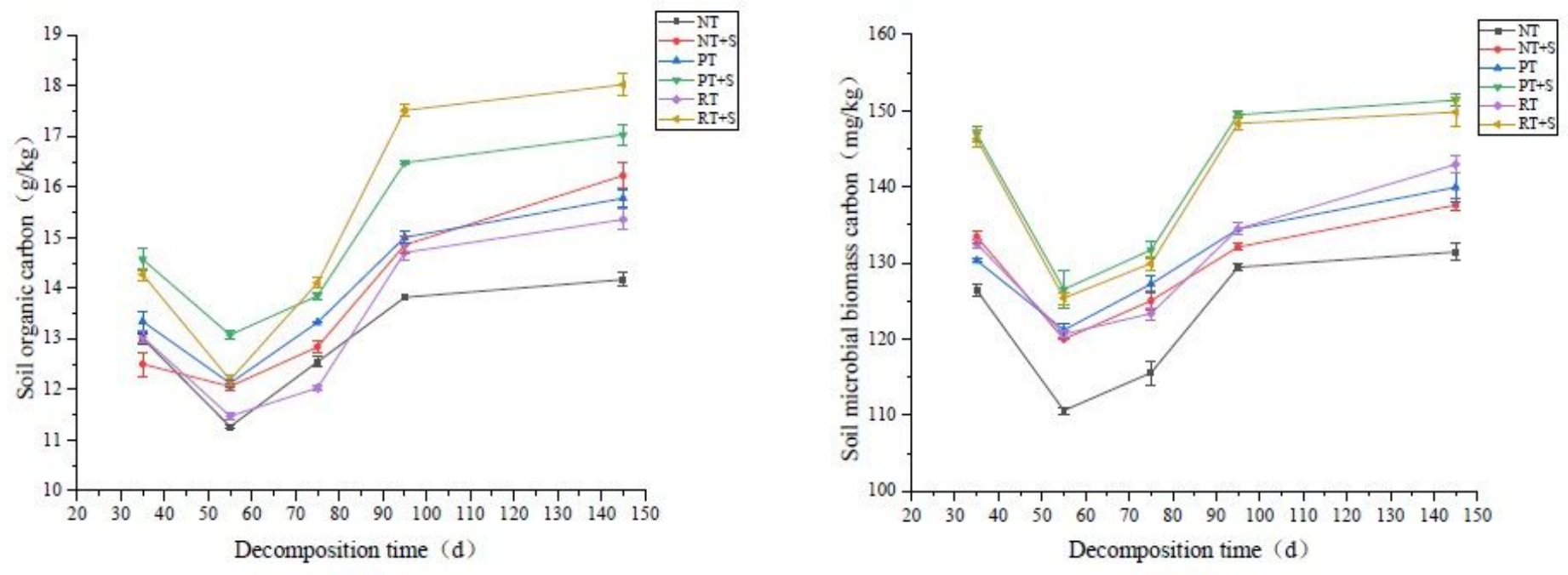

\section{Figure 5}

Changes of soil organic carbon and microbial biomass carbon under different returning modes. 


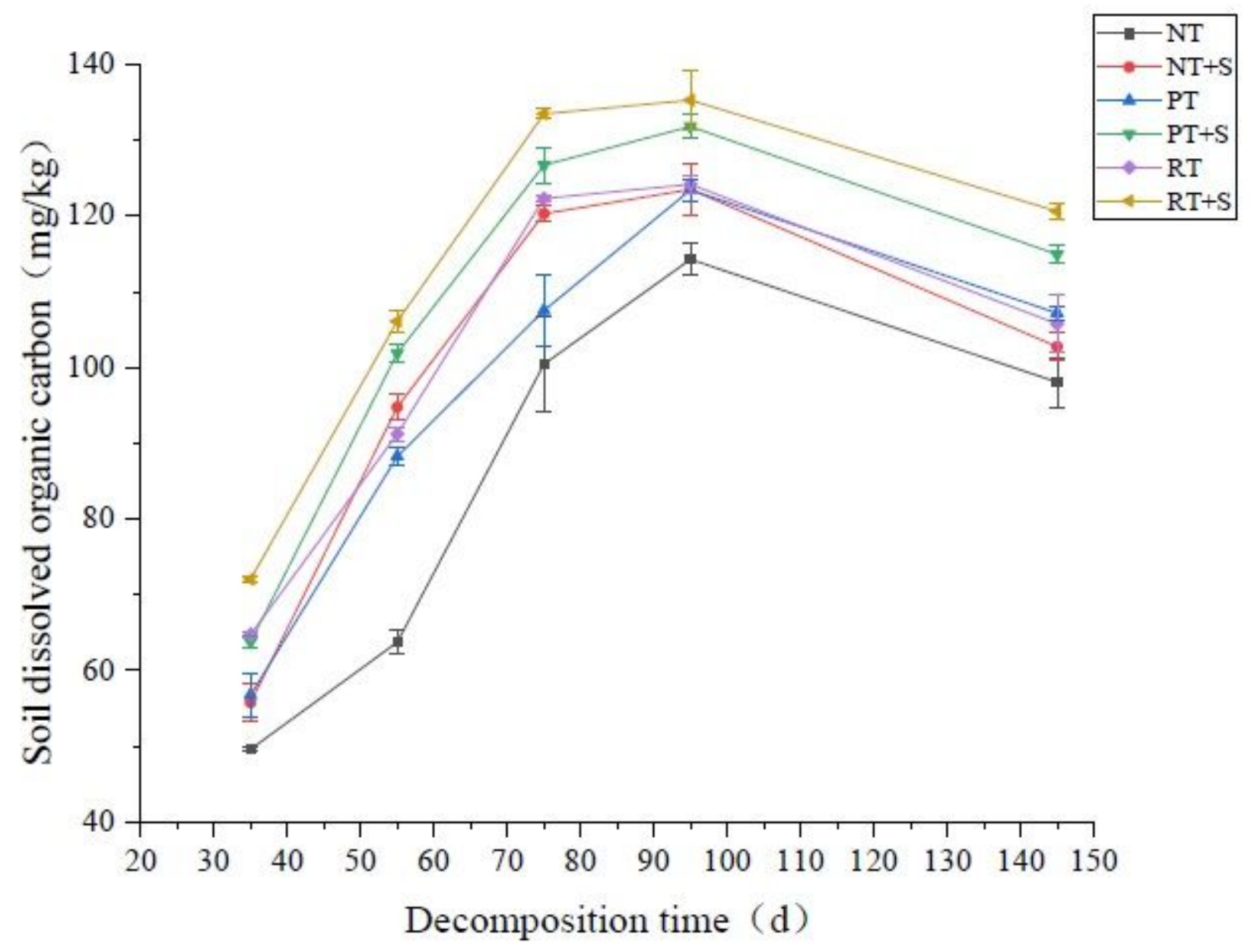

Figure 6

Changes of soil soluble organic carbon under different returning modes. 